\title{
ARE LOTS OF COLLEGE GRADUATES \\ TAKING HIGH SCHOOL JOBS? A \\ RECONSIDERATION OF THE EVIDENCE
}

John Tyler

Richard J. Murnane

Frank Levy

Working Paper No. 5127

\author{
NATIONAL BUREAU OF ECONOMIC RESEARCH \\ 1050 Massachusetts Avenue \\ Cambridge, MA 02138 \\ May 1995
}

This paper is part of NBER's research program in Labor Studies. Any opinions expressed are those of the authors and not those of the National Bureau of Economic Research.

(C) 1995 by John Tyler, Richard J. Murnane and Frank Levy. All rights reserved. Short sections of text, not to exceed two paragraphs, may be quoted without explicit permission provided that full credit, including $\odot$ notice, is given to the source. 


\title{
ARE LOTS OF COLLEGE GRADUATES \\ TAKING HIGH SCHOOL JOBS? A RECONSIDERATION OF THE EVIDENCE
}

\begin{abstract}
Several recent published papers have asserted that a growing proportion of workers with college degrees are either unemployed or employed in jobs requiring only high school skills. Using data from the 1980 and 1990 Censuses of Population and Housing, we show that this assertion does not accurately reflect labor market trends for young (25-34 year old) male or female college graduates or for older (45-54 year old) female college graduates. For all these groups, real earnings increased during the 1980s and the percentage in "high school jobs" declined. The assertion is valid only for older male college graduates. Young college graduates improved their labor market position during the 1980 s by increasingly obtaining degrees in occupations which had high earnings at the beginning of the decade and which had the highest earnings growth over the decade.
\end{abstract}

John Tyler

Graduate School of Education Harvard University

13 Appian Way

Cambridge, MA 02138
Richard J. Murnane

Graduate School of Education Harvard University 13 Appian Way Cambridge, MA 02138 and NBER
Frank Levy

Department of Urban Studies and Planning M.I.T.

Room 9-515

77 Massachusetts Avenue

Cambridge, MA 02139 
Are Lots of College Graduates Taking High School Jobs?

A Reconsideration of the Evidence

by John Tyler

Richard J. Murnane

Frank Levy ${ }^{1}$

Introduction

Mass upward mobility through education is a central belief in American society.

Since World War II, this belief has centered increasingly on the value of a college education. But twice in the last 25 years, the economic value of college has been called into question by labor market developments.

The first challenge arose in the late 1960s and continued through the 1970 s as college-educated baby-boomers surged into the labor market and sharply depressed a college diploma's economic return. ${ }^{2}$ By the early 1980 s, however, wages for less educated workers had collapsed while the earnings of college graduates held their own. A college education looked like a good investment once again.

The second challenge came in a 1992 article in this journal written by BLS economist Daniel Hecker. Using occupational and demographic data from the Current 
Population Survey, Hecker estimated that in 1990, 20 percent of all workers with college degrees were either unemployed or employed in jobs requiring only high school skills. ${ }^{3}$ This figure, he argued, had risen significantly since 1970 when only 11 percent of college-educated workers were similarly underemployed. Put simply, there were too many college graduates.

Hecker's article, published during the 1989-92 white collar recession, was quickly taken up by the popular press. An example was an August 1992 Newsweek column in which economics reporter Robert Samuelson wrote:

... (Hecker) convincingly demolishes the notion that there's a scarcity of college graduates and that sending more Americans to college will automatically create a more productive economy...[If] more people had gone to college in the 1980s they would have competed mostly for lower-wage jobs that usually don't require a degree." ${ }^{4}$

In a similar vein, New York Times reporter Sylvia Nasar wrote a 1992 story, "More College Graduates Taking Low-Wage Jobs," ${ }^{5}$ in which she emphasized the irony of Hecker's findings coming at a time:

when college enrollments are at record levels, tuition is at an all-time high and the most costly item in Bill Clinton's economic plan is a program to send everyone to college who wants to go.

Hecker's message was updated and reinforced in the Summer 1994 Occupational Outlook Quarterly, an issue devoted to the college labor market. The issue's lead article by BLS economist Kristina Shelley began with the warning: 
The employment outlook for college graduates between 1992 and 2005 is like a weather forecast in the midst of the summer doldrums: Tomorrow will be a rerun of today -- or a little worse. ${ }^{6}$

Each of these articles contains the same warning: The economy is generating college graduates faster than it is generating jobs for those graduates. Potential college students and those who design educational policy ignore this fact at their peril.

In this paper, we demonstrate that the warning is largely misguided and that a college education continues to have significant economic value. We reach our conclusion by probing the details of Hecker's analysis. Greater detail is needed because Hecker's conclusion is based on a highly aggregate statistic: the 1970-90 change in the proportion of all college graduate workers holding high school jobs. By contrast, persons now concerned with the value of college - potential students and policy makers - need to look specifically at recent changes in the market for young college graduates.

To see why this is so, note that Hecker's main finding may reflect any of several, quite different situations:

- A growing number of recent college graduates now working in latte' bars or other jobs for which they are over-educated. This is the situation assumed by most of Hecker's readers.

- A growing number of middle-aged college graduate managers who lost their positions in 1980s' white collar restructuring. ${ }^{7}$

- One or more events that took place entirely in the 1970 s and have little relevance for current decisions.

If, in this period of rapid technological change, older and younger college 
graduates are not close substitutes in production, only the first of these situations raises serious doubts about going to college today.

In a similar vein, more detail is needed on the meaning of "high school jobs" - jobs that seem to require only a high school education. As the Samuelson quote suggests, Hecker's readers assume a high school job is one which pays a high school wage even to a college graduate. But this is only an assumption since Hecker does not report wage data. College graduates in high school jobs will probably have lower earnings than other college graduates, but they still may earn more than high school graduates in similar jobs. Anecdotal evidence suggests that skill requirements have been rising within some occupations titles. If that has happened, it is possible that certain high school jobs now require college graduates and employers are willing to pay to get them.

To summarize, for Hecker's findings to be relevant to today's college-related decisions, three facts must hold:

Point I The nine percentage point increase in the share of college educated workers in "high school jobs" between 1970 and 1990 must be a continuous development - not a development confined to the 1970s.

Point II Recent increases in the proportion of college educated workers in "high school jobs" (if increases exist) must include recent college graduates - not just older workers.

Point III "High school jobs", as Hecker defines them, must pay "high school wages" to anyone who holds them including college graduates.

In the remainder of this paper, we address each of these points in turn and show that 
all of them are largely false. In absolute terms, 1989 young college graduates were doing as well as (men) or better than (women) their 1979 counterparts. This conclusion applies to both young BA's and young post-graduates. ${ }^{8}$ To the extent that a growing proportion of college graduates took high school jobs in the 1980s, it was older men (but not women), victims in part of white collar restructuring. By contrast, young men and women proved adept at moving into occupations that were expanding and had high wages.

We make this argument in six sections. In the next three sections, we address the three points listed above - the time path of the movement into high school jobs, the extent to which recent graduates were hurt in the 1980 s, and the pay received by college graduates in high school jobs. In Section IV, we examine the way in which young graduates in the 1980s followed market signals to upgrade their position. In Section V, we reconcile our generally optimistic data with numerous anecdotes of young college graduates who are having trouble getting started. Section VI contains our conclusions.

\section{Point I: The Time Path of the Trend}

As Hecker demonstrates, the proportion of BA's and post-graduates who are either unemployed or in high school jobs rose from 11.3 percent in 1970 to 19.9 percent in 1990. This difference between end-points has been widely quoted. The path between the two-end points has received less attention. That path, reproduced from Hecker (1992), appears in Table 1 and shows that most of the rise - from 11.3 percent to 18.6 percent - 
occurred between 1970 and 1980 . Between 1980 and 1990, the proportion increased only by an additional 1.3 points.

The concentration of the problem in the 1970s is what we would expect from a steady demand shift toward college graduates operating against a 1970s surge in supply. ${ }^{9}$ As we noted, the 1970s were the decade in which the big, well-educated cohorts of the baby boom first began their careers. Between 1970 and 1980, the number of workers with at least 4 years of college grew by an astounding 7 percent per year. From 1980-89, the number of workers with at least 4 years of college grew by 4.5 percent per year, ${ }^{10}$ a figure more in line with the economy's absorptive capacity and a figure more in line with future supply growth. We return to this point in Section II.

In sum, the supply of college graduate workers grew at a robust annual rate in the 1980s, while the proportion of these workers in high school jobs increased only a little. This suggests that at least aggregate demand for college graduates remained strong in the 1980s. But strong aggregate demand for college graduates could mask falling demand for new entrants and, it is to that subject that we now turn.

\section{Point II: How did Young College Graduates do in the 1980s?}

Did the modest 1980s shift of college graduates into high school jobs mask a bigger shift among young college graduates? To answer this question, we examine changes between 1979 and 1989 using data from the 1980 and 1990 Public Use Microdata 1 
percent Samples of the U.S. Census of Population and Housing. ${ }^{11}$ To keep our analysis manageable, we begin by focusing on eight (age/sex/education) groups of workers:

- 25-34 year old men and women with exactly 12 completed years of schooling.

- 25-34 year old men and women with exactly 16 completed years of schooling.

- 45-54 year old men and women with exactly 12 completed years of schooling.

- 45-54 year old men and women with exactly 16 completed years of schooling.

Where Hecker combined BA's and post-graduates, we focus here on BA's per se, persons whose experiences are most relevant to young people considering college. Using these groups, we can see whether different age/sex groups of BA's had to take high school jobs at different rates. We can also measure the experience of 1989 BA's against two yardsticks: 1979 BA's, and high school graduates in 1979 and $1989 .{ }^{12}$ We consider the experience of post-graduates at the end of this section.

Table 2 describes the 1979 and 1989 labor market experience of our four groups of BA's: 25-34 year-old (hereafter, "young") men and women and 45-54 year-old (hereafter, "older") men and women. The table includes data on each group's median earnings in $\$ 1990$ and the proportion of each group in "high school jobs", using Hecker's occupational classification. ${ }^{13}$

As the data show, neither young women nor young men (nor older women) display 
the kind of labor market decline implied by Hecker's article. Among both young and older women 1989 median earnings were higher than the earnings of their 1979 counterparts. Similarly, the fractions of young and older women in high school jobs were lower in 1989 than in 1979. Young men similarly show no deterioration: median earnings are slightly higher in 1989 than in 1979, and the proportion of such men in high school jobs declined slightly during the decade. ${ }^{14}$

In Table 2 as in Table 1, we cannot interpret the figures for young workers without discussing changes in labor supply. Between 1980 and 1990 the labor supply of young male and female BA's grew by 60 percent. This growth represented a slowdown from the 1970 s when the baby-boomers first arrived in force, but it is a much higher growth rate than any we will see in the near future, regardless of how many high school graduates go to college.

The difference is demographics. Between 1979 and 1989, the last baby-boom cohorts were turning age 25 . The number of 25-34 year-olds in the population (regardless of education) grew by 19 percent. Between 1991 and 2,001, the total number 25-34 yearolds will decline by 17 percent. Even if young people go to college in record proportions, they will not produce anything like a 60 percent increase in the number of young BA's an increase that the 1980 s economy successfully absorbed.

Of the four groups in the table, the picture of excess supply only fits older men. Between 1979 and 1989, the real median earnings of older male BA's fell by 4 percent 
while the proportion in high school jobs increased from 14.5 percent to 17.9 percent. While these results point to recent white collar restructuring, the truth is more complicated. Like the rest of these data, the data in Table 2 compare counterparts: men who were 45-54 in 1979 and men who were 45-54 in 1989. Synthetic cohort analysis, not reported here, suggests that the 1989 group already had a somewhat higher proportion of high school jobs in 1979 (when they were ages 35-44) and only half of the observed increase in high school jobs actually occurred to these men in the 1980s.

In any era, older BA's are imperfect substitutes for younger ones. In the current era, rapid technological change may diminish substitution possibilities further. For this reason, the most relevant data for current college decisions are the recent labor market experiences of young BA's. As shown in Table 2, this recent experience has been reasonably good.

Table 3, Panel A, emphasizes this point by comparing the earnings and hourly wages of young BA's and young high school graduates. These results, familiar to most readers, illustrate that while BA earnings grew for young men (modestly) and young women (strongly), high school wages fell for both young women and (more sharply) for men. Relative to a high school diploma, the value of a BA increased significantly.

Table 3, Panel B, uses similar data to address a point made by Hecker in a February 1995 article in this journal, an update of his 1992 article. $^{15}$ As Hecker notes, in 1992, 20 percent of college graduates (all ages and degrees) had earnings below the median 
earnings of persons with high school diplomas, more evidence, he suggests, of an excess supply of college graduates. For decisions about college, however, what is relevant is not the level of the statistic at a point in time but the statistic's trend. Table 3, Panel B contains these data for young men and women and shows that during the $1980 \mathrm{~s}$, the proportion of young BA's with earnings below the high school median was falling for both sexes.

We turn finally to the recent labor market experience of post-graduates. Appendix Table A reproduces Table 2 for workers with more than four years of college. ${ }^{16}$ The trends are consistent with the experience of BA's.

Over the 1980s, young women and men and older women post graduates all experienced sharp median earnings gains while older men experienced more modest gains. Similarly, young women, young men and older women post graduates experienced moderate declines in the proportion holding high school jobs while older men experienced a small increase.

We note one quirk in the data. Appendix Table A focuses on post-graduates. If it had focused instead on BA's and post-graduates combined, it would have shown the proportion of young workers in high school jobs rising slightly during the decade. It would have shown this result despite the fact that young BA's and post-graduates were both doing better in 1990 than in 1980 .

The paradox is explained by composition bias. Between 1980 and 1990, the number of 
young BA's increased far more rapidly than the number of young post-graduates. For example, among young men, persons with just a BA comprise about 62 percent of the combined 1980 group and 75 percent of the 1990 group. In both 1980 and 1990, young post-graduates have higher median earnings and lower proportions in high school jobs than young BA's. The 1990 group suffers, cet. par., because it contains a smaller share of the higher-performing group.

\section{Point III: What do High School Jobs Pay BA's?}

Table 4 displays the median earnings of BA's in "high school jobs" (using Hecker's classification), and the ratio of these earnings to the median earnings of high school graduates in the same set of jobs.

To place these data in context, recall that growing earnings inequality during the $1980 \mathrm{~s}$ involved two trends: a widening earnings gap between workers of different educational levels and a growing "within-group" inequality among workers of the same educational level. ${ }^{17}$ The data in Table 4 demonstrate both of these trends.

Begin with the case of young men. Recall from Table 2 that young male BA's had roughly equal median earnings levels in 1979 and 1989. Growing within-group inequality around a constant average points to lower real earnings for the worst-off BA's and higher real earnings for the best-off BA's.

As shown in Table 4, young male BA's in high school jobs - presumably some of the 
worst off male BA's - had median earnings of $\$ 23,115$ in 1979 , while their 1989 counterparts had median earnings of $\$ 20,963$, a decline of 9.4 percent. The combination of declining earnings among the worst off and a steady median indicates a growing within-group inequality among these young male BA's.

At the same time, the data show a growing BA-high school earnings gap for young men in these high school jobs. In 1979, young male BA's in high school jobs were earning 5 percent less than young male high school graduates in the same occupations. By 1989 , young male BA's were earning 8 percent more than young male high school graduates in those jobs. The pattern for older men is similar.

The earnings of young female BA's exhibit the same pattern in a somewhat different form. For these women, within-group earnings inequality increased because earnings at the bottom of the distribution grew but earnings in the middle (and top) of the distribution grew faster: median earnings grew by 13.5 percent among young female BA's in high school jobs (Table 4) and by 22.5 percent among all young female BA's, regardless of job (Table 2). As was the case for young men, the earnings gap between young female BA's and young women high school graduates in high school jobs widened over the decade. The data for older female BA's tell a similar story.

To summarize, the 1980 s were an era of growing inequality in which there was a growing earnings gap between workers in the bottom of any group - young high school graduates, older BA's - and the average worker in that same group. In our case, this means 
that the earnings gap between the average young BA graduate and the young BA in a high school job grew over the decade. But this is quite different than saying BA's in high school jobs should have not gone to college at all. To the contrary, 1980s trends indicate a growing differentiation between BA's and high school graduates within high school jobs which suggests that a BA has growing value even among those graduates who are doing most poorly.

\section{How Did Young BA's Do it?}

How were young college graduates in the 1980s able to avoid the fate Hecker's article suggests? To answer this question, it is useful to look at the occupations they chose.

Figures 1 and $2^{18}$ display the occupational distributions of the young female and male BA's. In both 1980 and 1990, young female BA's were largely employed in three occupational groups -- administrative support, professional specialties, and executive and managerial occupations (Figure 1). Over the decade, however, the share of young women in professional specialties declined significantly, a point we return to below.

Over the same period, young male BA's were concentrated in white collar and supervisory occupations, ${ }^{19}$ professional specialties, and executive and managerial positions (Figure 2). Among such young men, however, the share employed in professional specialty occupations increased over the decade. 
Figures 3 through 6 explain why professional specialty occupations play a key role in our story.

Figure 3 displays the employment share distributions within professional specialties for young female BA's in 1980 and their 1990 counterparts. In both years, young female BA's were employed primarily in health occupations and in education. But the 1990 cohort of young females display a striking trend: all of their reduced employment share in professional specialties reflect declining employment levels within education and social sciences, while their employment shares in all other professional specialty occupations increased.

The impact of this shift on the annual earnings of the 1990 young cohort of females is evident in Figure 4. Education - the occupational category with the falling share of young female BA's - had a low earnings level. Three of the categories with growing shares of young female college graduates had earnings that were high and rising. Put differently, the shift of young female BA's within professional specialties reflected responses to market signals.

Figures 5 and 6 present a similar follow-the-market story for the 1990 young men. Young male BA's in 1990 had higher employment shares in professional specialties than did their counterparts in 1980 . Figure 5 shows that virtually all of this increase occurred in engineering, the sciences, and health, and that, in fact, the 1990 young male cohort had decreased relative shares in education and the social sciences. 
The distribution of median earnings by occupation in Figure 6 shows the effect of these shifts in employment shares on young male BA annual earnings. As with the 1990 young women, the three categories where young male BA's congregated in 1990 were the three categories where annual earnings are the highest and grew the most over the 1980s - engineering, the sciences, and health occupations. And as with the young female BA's in 1990 , the young men had substantially reduced employment shares in the low paying field of education.

The message of Figures 3 through 6 is that young male and female college graduates were very responsive to market signals regarding employment and earnings opportunities. Both groups increasingly earned degrees in those occupations which had higher earnings levels at the beginning of the decade and which had the greatest earnings growth over the decade: highly technical fields such as engineering, the sciences, and health. Correspondingly, fewer young men and women opted for degrees which led to lower paying careers in education and the social sciences.

\section{What About the Latte' Bars?}

Every reader of this paper will have an anecdote about some new college graduate - a child, a friend, a child of a friend - who is having trouble getting launched. Anecdotes make strong impressions and even a charitable reader may conclude that we are right about the 1980s, but that the world has changed since then. 
A changed world, however, is not the only way to reconcile anecdotes with the data. Most anecdotes about getting started describe 22 or 23 -year-olds. The "young worker" data in Table 2 describe the median earnings of 25-34 year-olds - roughly speaking, the earnings of a 30-year-old. Anecdotes and data can both be right if young people do a lot of "getting on track" between the ages of 22 and 30.

In Figure 7, we show median annual earnings for female and male BA's at ages 22, 23, ... up through age 30, in both 1979 and 1989. The figures show that in both 1979 and 1989, 22 and 23-year old BA's had quite low earnings in line with the anecdotes. But the figures also show that young BA's make substantial progress during their 20s so that by the time they are 30 , their earnings resemble the data in Table $2 .{ }^{20}$

We do not mean to minimize the problem of getting started particularly in an economy with significant white collar restructuring. But we should not let the anecdotes obscure the fact that newly minted BA's working in latte' bars (or their equivalent) is nothing new, and that working in a latte' bar at age 22 does not mean working in a latte' bar at age 30 .

\section{Conclusion}

Daniel Hecker's picture of a growing number of college graduates in high school jobs has become one of those "facts" everyone knows. The fact has been taken, particularly by the media, as evidence that expanding access to college is no longer a sensible thing to do. 
In this paper, we have argued that the "fact" was largely an experience of the 1970s. Over the 1980s, by contrast, the absolute value of a college diploma has held its own for young men and increased for young women, as both groups responded to market signals. These facts have been obscured by the way in which college graduates often take two or three years to get started.

Over the 1980s, a college diploma's value relative to a high school diploma has also increased. The widening college-high school earnings gap has been demonstrated by many authors. ${ }^{21}$ But as we show in this paper, the gap has widened even for young men and women employed in "high school jobs".

We do not conclude from this analysis that everyone should go to college. Rather, we conclude that gluts and shortages of college graduates should be determined in the old fashioned way - by looking at prices and quantities. Other kinds of data like occupational skill requirements can tell interesting stories. But when those stories conflict with market data about prices and quantities, it is the market that we should believe. Right now, the market says a college education remains a good idea. 
Table 1. Hecker's numbers on percentage of college graduates in "high school-type" jobs.

\begin{tabular}{lcc}
\hline Year & $\begin{array}{c}\text { Percent in "high school- } \\
\text { type" jobs or unemployed }\end{array}$ & $\begin{array}{c}\text { Percent in "high school-type" } \\
\text { jobs" }\end{array}$ \\
\hline & & \\
1967 & 11.7 & 10.9 \\
1970 & 11.3 & 10.0 \\
1975 & 16.7 & 14.2 \\
1980 & 18.6 & 16.9 \\
1985 & 19.2 & 17.1 \\
1990 & 19.9 & 17.9 \\
\hline \hline
\end{tabular}

Source: Daniel Hecker. "Reconciling conflicting data on jobs for college graduates," Monthly Labor Review, July 1992. 
Table 2. Comparison of median annual earnings, 1979 and 1989, for BA's with positive earnings (1990\$).

Cohort

1979

1989

'79-'89

chng.

YOUNG FEMALES

Median earnings

$\$ 17,961$

$\$ 22,011$

$+22.5 \%$

Percent in HS Jobs

28.2

25.2

-3.0 pts.

YOUNG MALES

Median earnings

Percent in HS Jobs

$\$ 28,981$

$\$ 29,841$

$+3.0 \%$

25.0

23.2

$-1.8 \mathrm{pts}$.

OLDER FEMALES

Median earnings

Percent in HS Jobs

$\$ 19,561$

$\$ 24,107$

$+23,2 \%$

27.6

23.6

-4.0 pts.

OLDER MALES

Median earnings

Percent in HS Jobs

$\$ 48,000$

$\$ 46,119$

$-3.9 \%$

14.5

17.9

+3.4 pts. 
Table 3. (Panel A) Median annual earnings and wages of BA's and high school graduates, males and females, and (Panel B) the percentage of male and female BA's with annual earnings below the median high school earnings level, 1979 and 1989 (1990\$).

Cohort and Labor Market Measure 1979

'79-' $89 \%$ change

Panel A

YOUNG MALES

COLLEGE GRADUATES Annual earnings Hourly wages $\$ 28,661$ $\$ 29,348$ $+2.4 \%$ $\$ 13.95$ $\$ 14.11$ $+1.1 \%$

H.S. GRADUATES Annual earnings Hourly wages $\$ 24,893$ $\$ 20,685$ $-16.9 \%$

$\$ 12.41$

$\$ 10.08$ $-18.8 \%$

YOUNG FEMALES

COLLEGE GRADUATES Annual earnings Hourly wages $\$ 17,783$ $\$ 22,011$ $+23.8 \%$ $\$ 10.84$ $\$ 12.09$ $+11.5 \%$

H.S. GRADUATES Annual earnings $\$ 12,451$ $\$ 12,578$ $+1.0 \%$ Hourly wages $\$ 7.70$ $\$ 7.21$ $-6.4 \%$

Proportion of Young BA's Below the (Respective) High School Median Earnings Level

Panel B

MALES

.358

.250

$-30.2 \%$

FEMALES

.330

, 249

$-24.5 \%$ 
Table 4. 1979 and 1989 median annual earnings of BA's with positive earnings employed in "high school-type" jobs.

\begin{tabular}{|c|c|c|c|c|}
\hline Cohort & . & 1979 & 1989 & $\begin{array}{c}\text { '79-'89 \% } \\
\text { chng. }\end{array}$ \\
\hline \multicolumn{5}{|c|}{ YOUNG MALES } \\
\hline & Median earnings & $\$ 23,115$ & $\$ 20,936$ & -9.4 \\
\hline & Coll./HS earnings ratio & 0.95 & 1.08 & +13.7 \\
\hline \multicolumn{5}{|c|}{ YOUNG FEMALES } \\
\hline & Median earnings & $\$ 14,228$ & $\$ 16,143$ & +13.5 \\
\hline & Coll./HS earnings ratio & 1.18 & 1.40 & +18.6 \\
\hline
\end{tabular}


Occupational Distribution of 25-34 year-old Female BA's with positive earnings

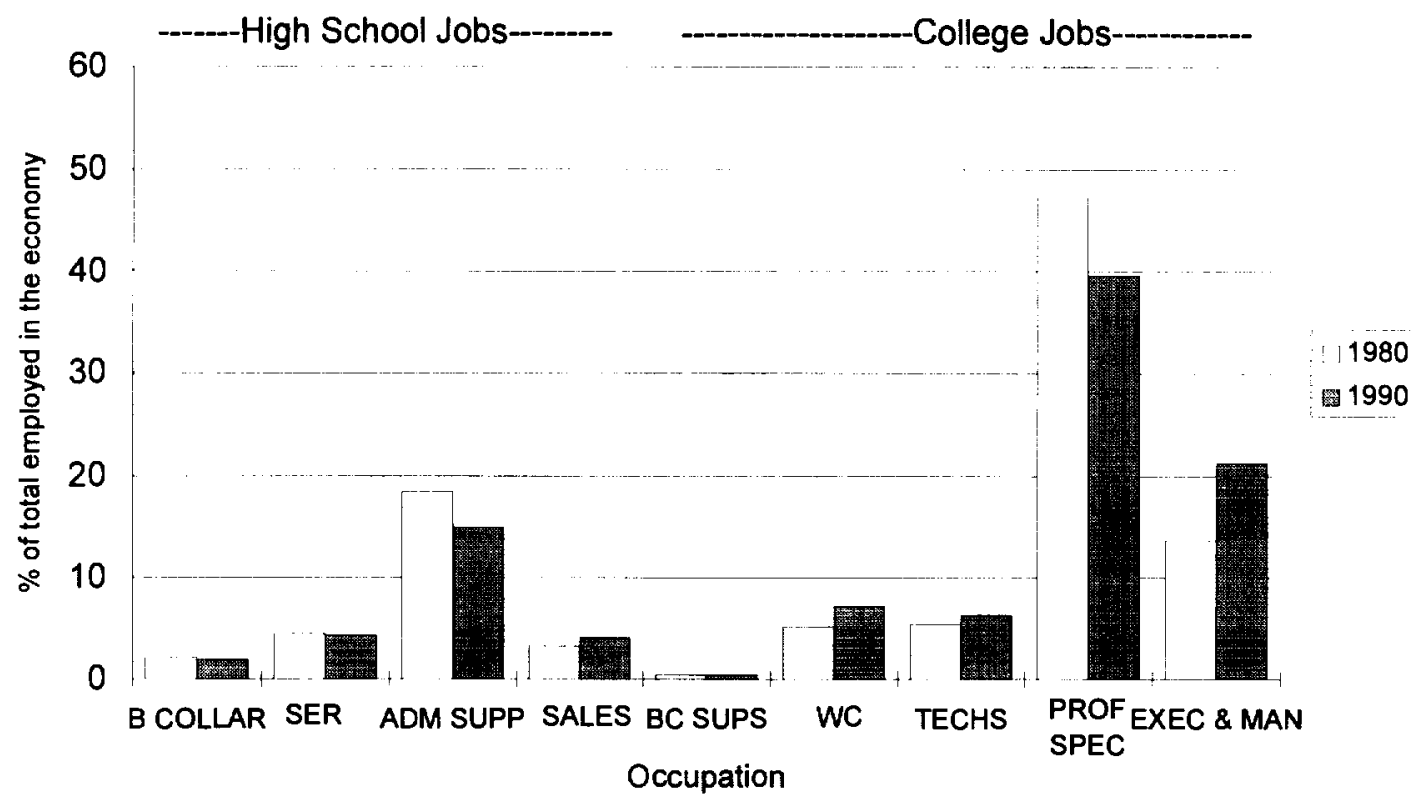

Figure 2

Occupational Distribution of 25-34 year-old Male BA's with positive earnings

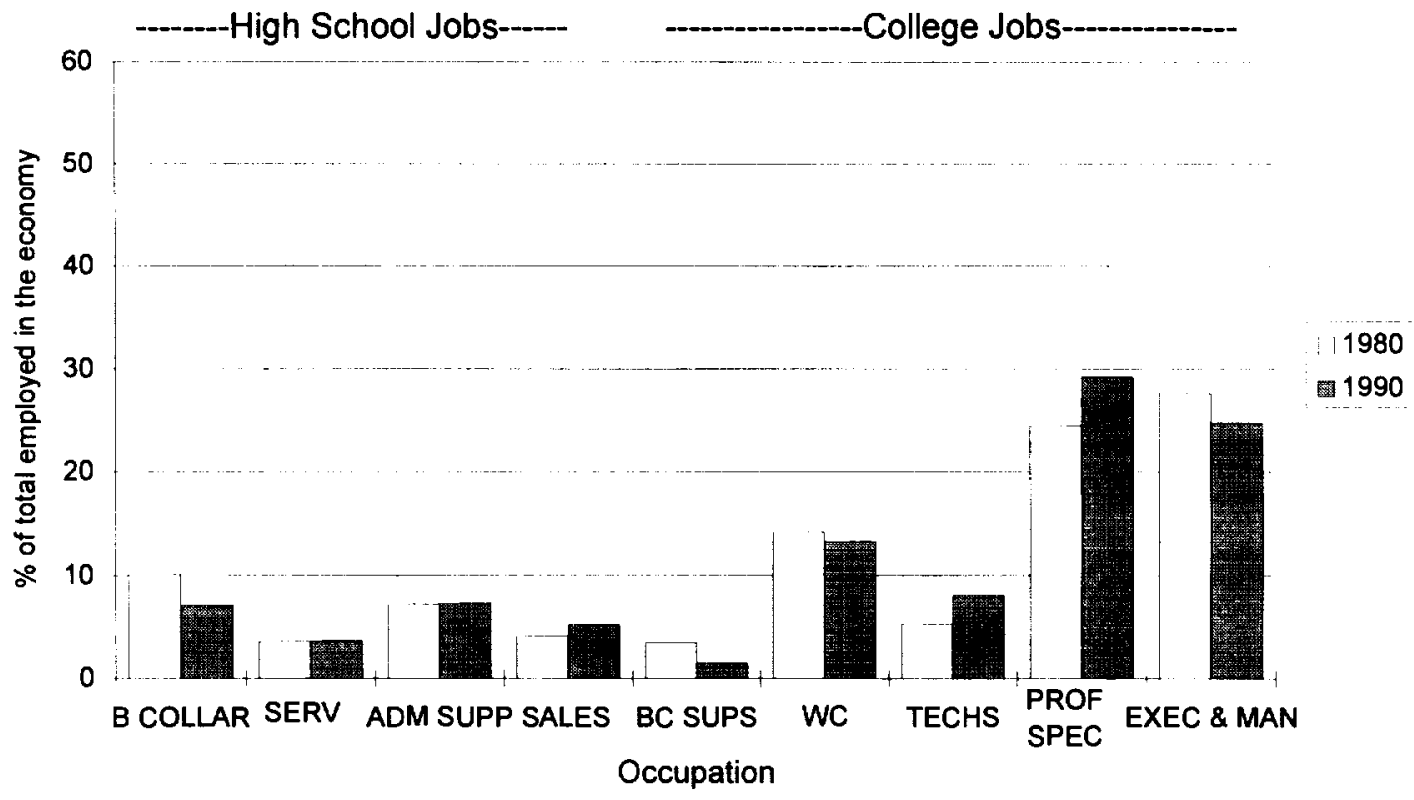


Figure 3

Occupational Distribution of 25-34 year-old Female BA's

with positive earnings and employed in Professional Specialities

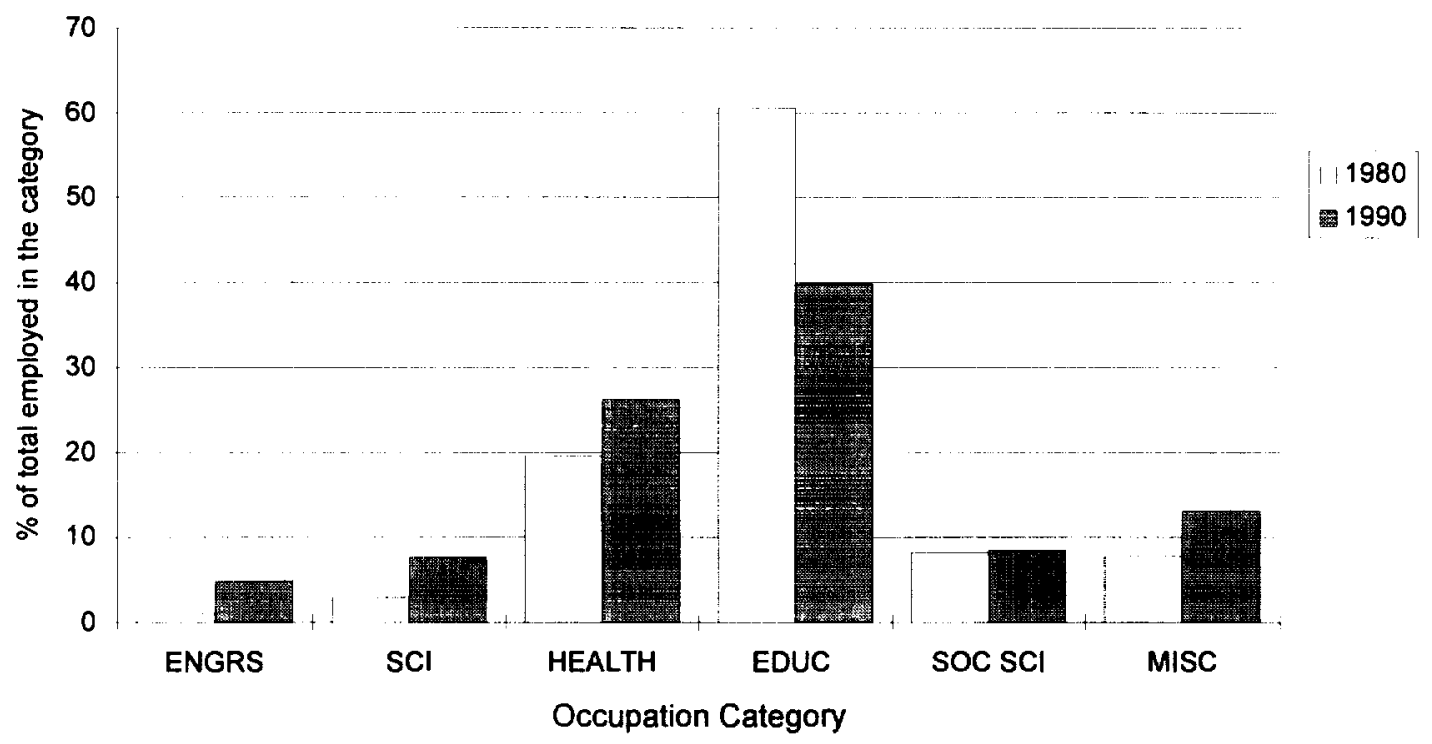

Figure 4

Median Annual Earnings of 25-34 year-old Female BA's with positive earnings and employed in Professional Specialities (1990\$)

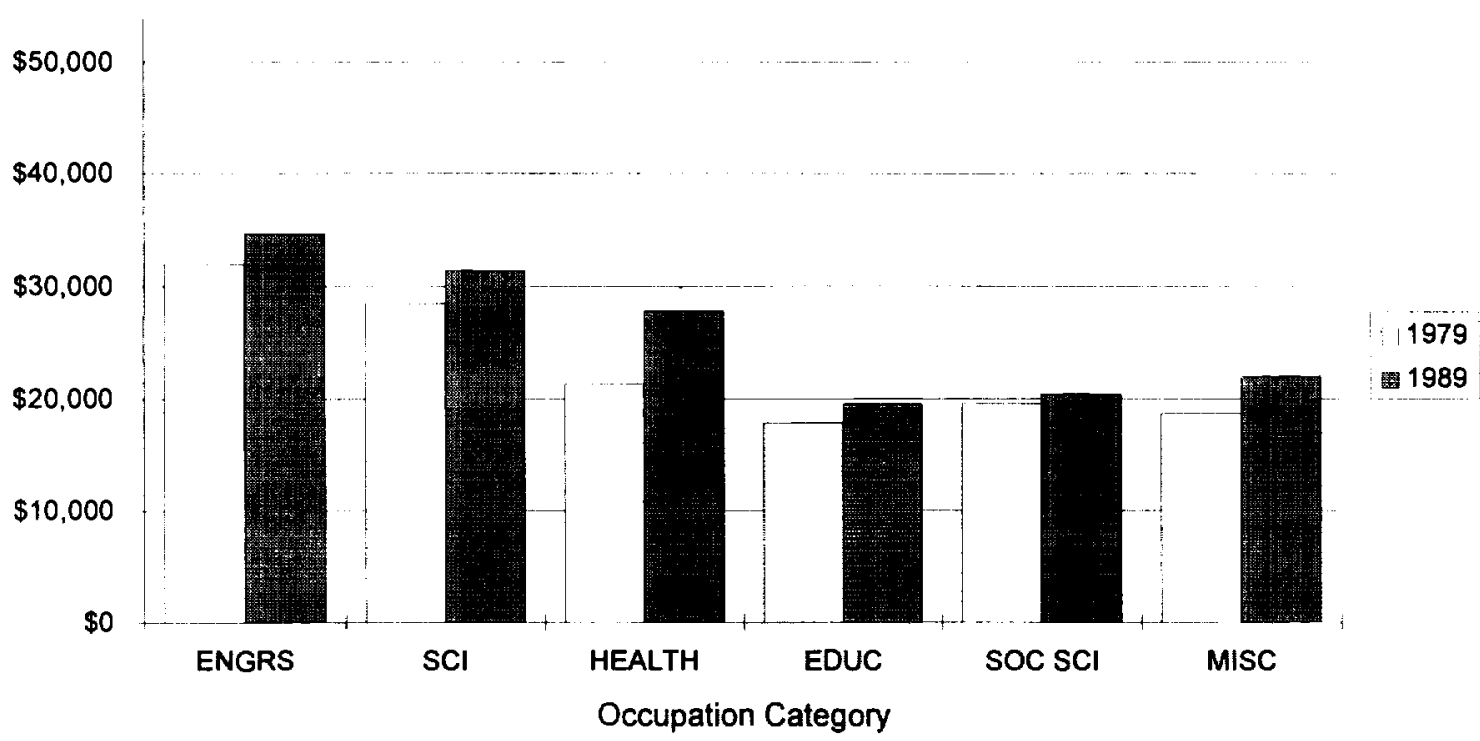


Figure 5 Occupational Distribution of 25-34 year-old Male BA's with positive earnings and employed in Professional Specialities

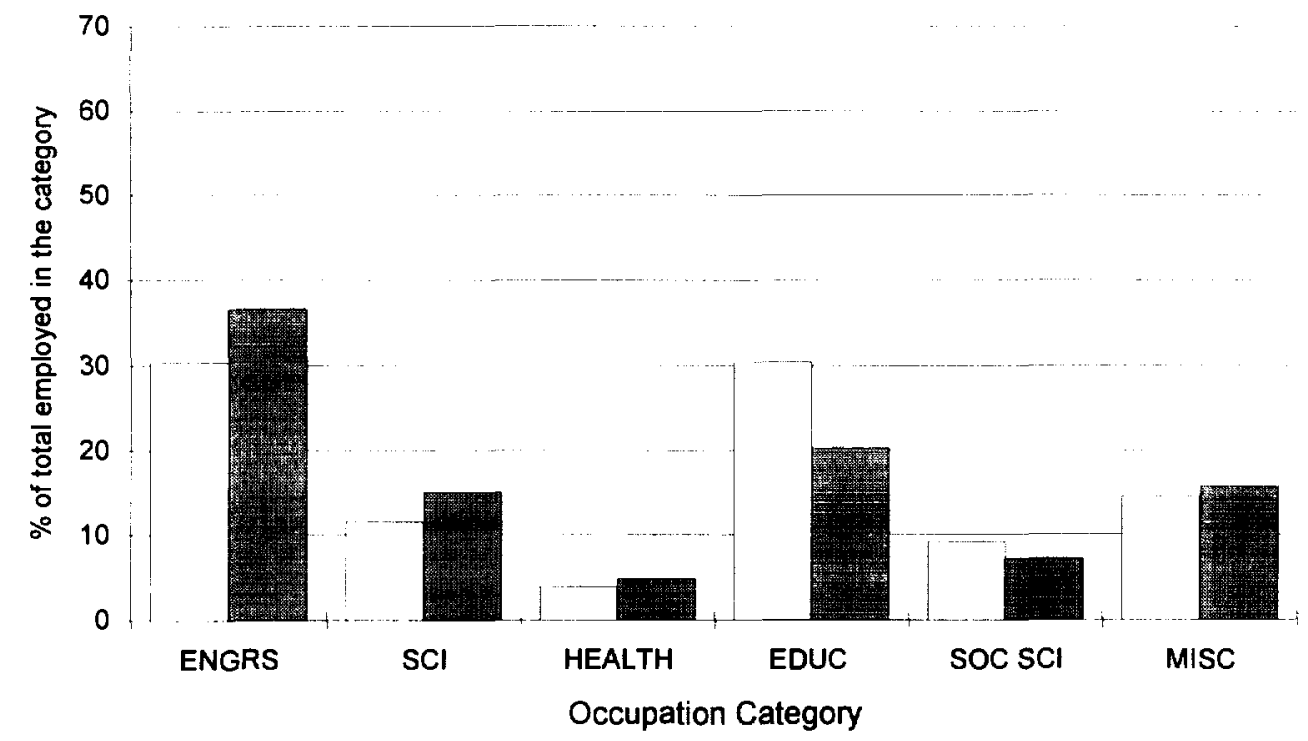

Figure 6

Median Annual Earnings of 25-34 year-old Male BA holders with positive earnings and employed in Professional Specialities (1990\$)

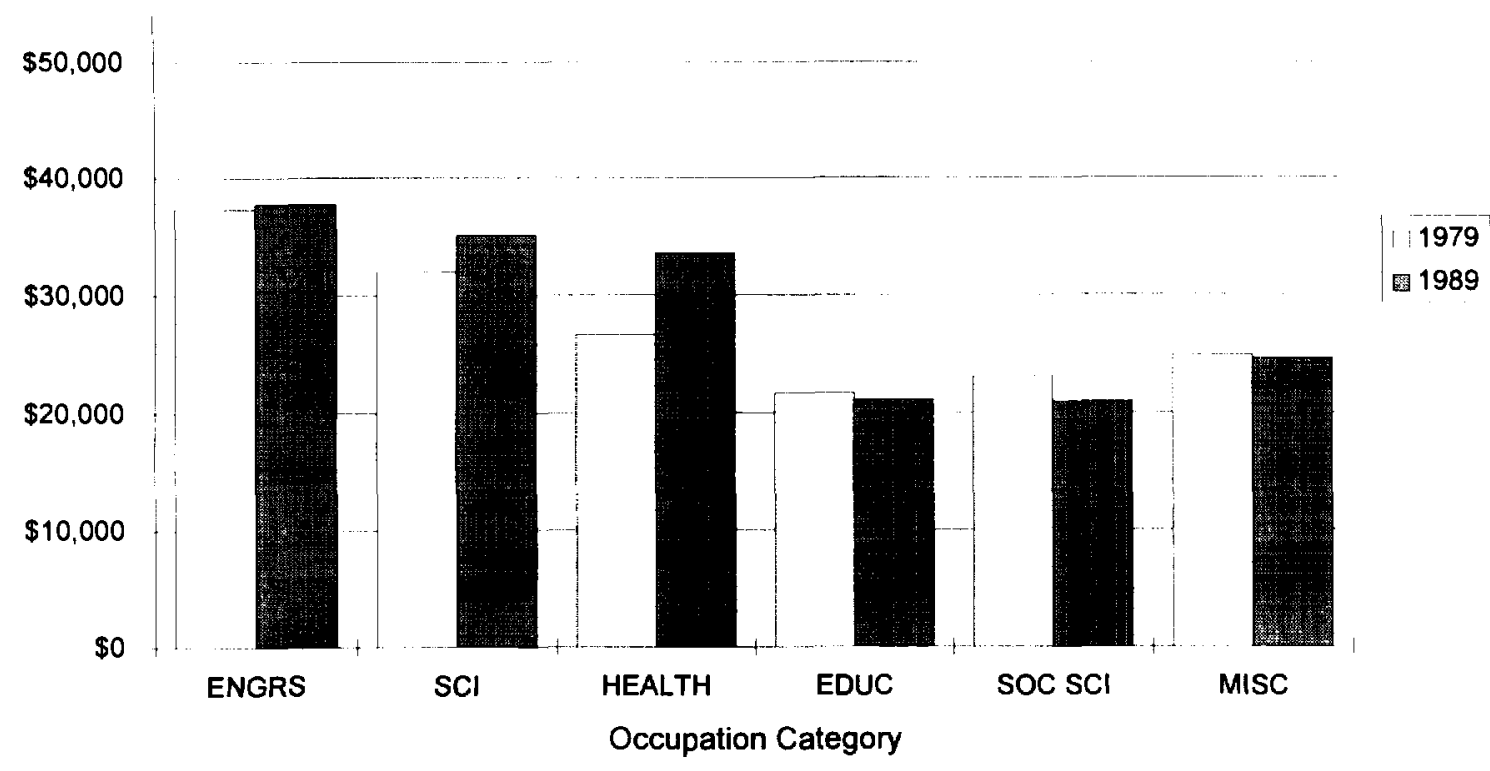


Figure 7 Median Annual Earnings of BA's with Positive Earnings, ages 22-30 (1990\$)
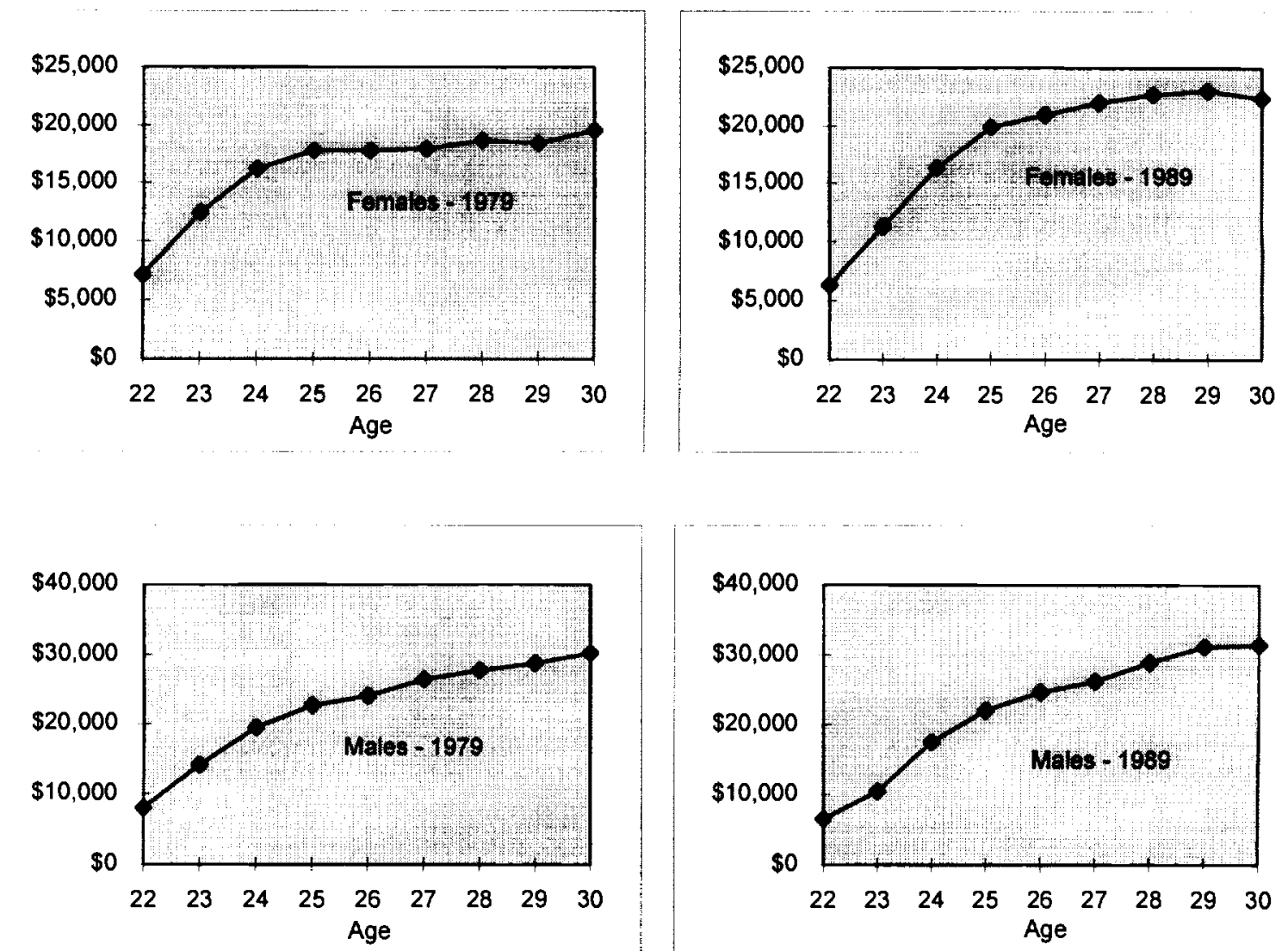


\section{Appendix}

Table A. Comparison of median annual earnings, 1979 and 1989, for post-graduates with positive earnings (1990\$).

Cohort

1979

1989

'79-'89 chng.

YOUNG FEMALES

Median earnings

$\$ 21,338$

$\$ 25,757$

$+20.7 \%$

Percent in HS Jobs

13.6

11.6

-2.0 pts.

YOUNG MALES

Median earnings

$\$ 29,603$

$\$ 33,541$

$+13.3 \%$

Percent in HS Jobs

25.0

23.2

-1.8 pts.

OLDER FEMALES

Median earnings

Percent in HS Jobs

$\$ 27,479$

431,969

$+16.35$

10.4

8.8

$-1.6 \mathrm{pts}$.

OLDER MALES

Median earnings

$\$ 48,000$

$\$ 50,312$

$+4.8 \%$

Percent in HS Jobs

7.5

7.6

$+0.1 \mathrm{pts}$. 


\section{Endnotes}

1. John Tyler is a doctoral student at the Harvard Graduate School of Education. Richard J. Murnane is a Professor at the Harvard Graduate School of Education. Frank Levy is Rose Professor of Urban Economics, Department of Urban Studies and Planning, M.I.T.. The authors wish to acknowledge support from the Russell Sage Foundation, the Sloan Foundation, the Spencer Foundation, and the Rose Chair of Urban Economics.

2. See Richard B. Freeman, The Overeducated American. New York: Academic Press, 1976, for the most widely recognized development of this theme.

3. Daniel E. Hecker, "Reconciling conflicting data on jobs for college graduates," Monthly Labor Review, July 1992, pp. 3-12.

4. Robert J. Samuelson, "The Value of College." Newsweek, August 31, 1992, p. 75.

5. Sylvia Nasar, "More College Graduates Taking Low-Wage Jobs," The New York Times, August 7, 1992, p. 5.

6. Kristina J. Shelley, "More Job Openings--Even More New Entrants: The Outlook for College Graduates, 1992-2005," Occupational Outlook Quarterly, Summer 1994, Vol. 38, No. 2, pp. 4-9.

7. While the media dates white collar restructuring to the $1989-92$ recession, the process actually began in the mid-1980s propelled by the deregulation of the telephone industry, airlines, etc.

8. We use the term BA to refer to a person with a four-year college diploma. We use the term post-graduate to refer a person with five or more years of college.

9. See Katz and Murphy, "Changes in Relative Wages, 1963-1987: Supply and Demand Factors," Quarterly Journal of Economics, February 1992, pp. 35-78.

10. See, for example, U.S. Department of Commerce, Statistical Abstract of the United States: 1991, GP0, Washington,D.C. 1992, Table 634.

11. Census questions on earnings refer to the year prior to the survey. Thus, earnings and wages in this study are for 1979 and 1989. Occupations, on the other hand, refer to the year of the survey, and hence, occupational figures in this paper are for 1980 and 1990.

12. Between 1980 and 1990, the Census changed the precise questions it asks on individual's schooling. In 1980 we define a BA as one with 16 years of completed education. In 1990 we use only those individuals who give a bachelor's degree as the highest degree received. In tables where we compare college graduates to high school graduates, we exclude those with 
implicit hourly wages below one-half of the 1979 minimum wage and those with hourly wages over $\$ 100$ per hour. The lower cutoff in the rest of the study is $\$ 3$ per hour. We also exclude persons working in the military and in mining, forestry, fishing, and agriculture since wages in these sectors may understate actual compensation.

13. Hecker classifies workers as being in college jobs if they are employed in executive, administrative, and managerial occupations, professional specialties occupations, technical occupations, sales representatives, some of those listed as sales supervisors or proprietors, some law enforcement officers, and supervisors in both white and blue collar occupations. He classifies workers employed in the remaining sales occupations and in administrative support, service and blue collar occupations as high school jobs.

14. The twenty percent growth in annual earnings experienced by women should not be overstated. As is well known, the 1980 s, like much of the 1970 s were a period of slow wage growth. Correspondingly, a decomposition using mean changes in women's annual earnings shows that only about one-third of the 1979-89 gains reflect higher wages per se. The remainder of the gains come from increased hours of work (one-half) and the positive interaction between wages and hours (one-sixth). Mean earnings are used in these calculations because median earnings cannot be decomposed in this way. Among young women college graduates the 1979-89 the earnings change was 26.4 percent at the mean and 22.5 percent at the median.

15. Daniel E. Hecker, "Further analyses of the labor market for college graduates," Monthly Labor Review, February 1995, pp. 39-41.

16. See endnote 12.

17. In practice, within-group inequality had been growing since the early 1960's. See Levy and Murnane, "U.S. Earnings Levels and Earnings Inequality: A Review of Recent Trends and Proposed Explanations," Joumal of Economic Literature, Vol. XXX, September 1992, pp. 1333-1381, for a summary of explanations of this phenomenon.

18. The four occupational groups on the left -- blue collar, services, administrative support, and sales -- are all high school-jobs sector occupations, and the five occupational groups on the right -- blue collar supervisors, white collar workers and supervisors, technicians, professional specialties occupations, and executive and managerial occupations -- constitute the college-jobs sector.

19. Note that the aggregation "White collar and supervisory occupations" is not a D.O.T. occupational category, but rather, the result of designating occupations as being in the high school-jobs sector or the college-jobs sector. 
20. In "The Structure of Wages," Quarterly Journal of Economics, February 1992, pp. 285326 , Murphy and Welch similarly remark on the steepness of the age-earnings profiles for young, well educated workers.

21. Gary Burtless, ed., A Future of Lousy Jobs? The Changing Structure of U.S. Wages, The Brookings Institution, Washington, D.C., 1990. 